\title{
Development of Dachl Cross-Cultural Learning Designs
}

\author{
${ }^{1}$ Lilis Afifah, ${ }^{2}$ Dewi Kartika Ardiyani, ${ }^{3}$ Edy Hidayat, ${ }^{4}$ Sawitri Retnantiti \\ State University of Malang Jl. Semarang No.5, Sumbersari, Kec. Lowokwaru, \\ Kota Malang, Indonesia \\ Email: ${ }^{1}$ lilis.afifah.fs@um.ac.id, ${ }^{2}$ dewi.kartika.fs@um.ac.id, \\ 3edy.hidayat.fs@um.ac.id, ${ }^{4}$ sawitri.retnantiti.fs@um.ac.id
}

\begin{tabular}{l}
\hline Available Online: \\
\hline http://www.jurnal.unublitar.ac.id/ \\
index.php/briliant
\end{tabular}

History of the Article:

Received on November 2020

Accepted on March 2021

Published on May 2021

Pages 250-260

\begin{tabular}{l}
\hline Keywords: \\
\hline Learning design; cross culture; \\
DACHL \\
\hline
\end{tabular}

DOI:

http://dx.doi.org/10.28926/briliant .v3i4.589

\begin{abstract}
In learning German as a foreign language, the concept of DACHL has not been well recognized by every German teacher. For this reason, adjustments to learning materials, techniques, and learning strategies are considered important so that the German learning process does not only train language skills but also fosters a cross-cultural understanding of these countries and the Indonesian nation itself. This article attempts to describe the results of training activities for the preparation of cross-cultural learning designs for German language teachers at the SMA / MA / SMK levels throughout Malang. The method is designed by adopting an education and training system for ASN, namely on campus and off-campus. Despite undergoing method modifications as a result of the outbreak of the COVID-19 pandemic, training is going well. With simultaneous mentoring, collaboration, and collaboration, participants can receive the material well and simultaneously apply it in the form of a learning design.
\end{abstract}

\section{INTRODUCTION}

In principle, foreign language learning is inseparable from basic ideas about planning, preparation of learning steps, implementation, and also about how the assessment is carried out. With this idea, a teacher always thinks about how learning can go well, correctly, and effectively. Likewise in learning German as a foreign language, the preparation of a learning framework is carried out to achieve learning objectives, either individually by each teacher or as a group through their respective associations, such as the field of expertise group (Kelompok Bidang Keahlian/KBK) for lecturers in higher education or teacher groups (Musyawarah Guru Mata Pelajaran/MGMP) for high school teachers.

In Malang, 32 schools provide German in the learning process. From this number, it can be seen that compared to other foreign languages (other than English), German is included in the foreign language that is studied by most students at the SMA, MA, and SMK levels. A total of 40 German teachers from these schools are under the MGMP German Language Malang City and the German MGMP Malang Regency. Apart from the MGMP, these teachers are also part of the Malang branch of the Association of Indonesian German Language Teachers (Ikatan Guru Bahasa Jerman Indonesian/IGBJI) which also consists of lecturers from universities. Even though this association is based in Malang, many 
teachers who come from areas around Malang also join in this IGBJI activity, such as from Blitar and Probolinggo.

Routinely, IGBJI Malang branch holds a member meeting once every two months. The regular meeting is a forum for each member to share information, knowledge, and various tips on learning German that have been obtained by members from training and hospitation activities. Various pieces of training by members who come from lecturers in the context of community service have also been carried out, such as training on mapping the German National Examination questions (2017) and training for the preparation of the Independent Learning Activity Unit (2019). Based on the evaluation of the two activities, the teacher still wants further training on the preparation of lesson plans (RPP). Previously, through the MGMP the teachers had tried together to compile the lesson plans by way of sharing tasks, however, this effort was not successful because there was no strong motivation from each individual to complete the task.

In addition to the preparation of a lesson plan, what is no less important in learning is the mastery of the material that is owned by a teacher. When a teacher teaches a foreign language in class, the other knowledge that accompanies the foreign language will always be related to one another, especially the culture. As stated by (Shutevski, 2016), learning a foreign language that is not a lingua franca should help students to better understand the foreign world they will encounter in class, by discussing this foreign world they will be able to understand their world more clearly. Based on the author's observations through Field Practice Activity (Kajian Praktik Lapangan/KPL) assistance, currently, German language learning tends to reflect only the culture of Germany, even though German is the mother tongue with the most speakers in the European Union. Nearly 130 million people in Germany, Austria, Switzerland, Luxembourg, Belgium, Lithuania, and South Tyrol (Italy) use German as their mother tongue or as a regularly spoken second language (Matthias Bischoff, 2018). With these data, the concept of learning German should not only refer to Germany but also other countries that use it as a mother tongue. In this framework, the term German language learning with the concept of DACHL is also known (German "D", Austrian "A", Swiss "CH", and Lithuanian "L").

From the results of these observations, it can also be concluded that German language learning in schools in Malang currently tends to emphasize linguistic learning. On the other hand, cultural learning which should accompany linguistics is more ignored. This problem arises because of various factors, such as time constraints, teachers focus on the linguistic elements of the German language or the limited knowledge that teachers have about cultural aspects of DACHL countries.

For every German teacher, there are DACHL principles that must be known, namely Wer Deutsch lehrt und lernt, soll kulturell und sprachlich etwas über den gesamten amtlich deutschsprachigen Raum erfahren dürfen (Der Internationale Deutschlehrerinnen- und Deutschlehrerverband e. V. (IDV), 2017). What this means is that anyone teaching and learning German should know both culturally and linguistically of all officially German-speaking areas. For example, in the Zeit mit Freunden theme 'time with friends' there is a text which provides information about the mention of "tavern" in the German-speaking countries above. In the wine-growing regions of southern Germany, the term tavern is 
known as Straußwirtschaft, while the Austrians call it Buschenschank, and in Switzerland, it is called Besenwirtschaft (Dengler, S., Rusch, P., Schmitz, H., 2017).

Starting from the introduction of the DACHL concept, trainees were invited to further understand the DACHL principles and the importance of knowing these concepts. Next is a discussion about the integration of the DACHL concept in German language learning. By utilizing teaching materials or textbooks that have been used in the classroom, the teacher makes an analysis of these books based on predetermined criteria, such as whether the DACHL concept is listed explicitly or implicitly, whether the DACHL concept is presented in a particular section or is integrated into all material, etc. The next activity is an exercise in developing a learning model. Here the teacher makes a lesson plan which includes material about DACHL. The learning design that has been developed in groups is then presented in the form of micro-teaching.

Along with the issuance of the circular of the Minister of Education and Culture of the Republic of Indonesia number 14 of 2019 concerning the Simplification of the lesson plan (Rencana Program Pembelajaran/RPP), the need for RPP preparation is still considered necessary to make the learning process more focused. In this circular, it is explained that the preparation of the lesson plan must adhere to the principles of being efficient, effective, and prioritizing the interests of students. The lesson plan, which originally consisted of 13 main components, is currently simplified into three core components, namely learning objectives, learning steps, and assessment. Unlike the previous condition, where teachers had to follow certain formats stipulated by the education offices in their respective regions through their supervisors, currently, teachers are free to choose, compile, and develop lesson plans independently.

This training activity seeks to encourage teachers to create attractive learning designs according to their creativity, not sticking to certain formats as desired by the Minister of Education and Culture circular above. Basically, this DACHL cross-cultural learning design training for German language teachers has a target so that each trainee is able to integrate the DACHL concept in learning design and be able to apply it in real activities. For this reason, it needs to be realized that efforts to create a creative learning process must begin with the personal ability of the teacher to define learning objectives, integrate learner knowledge and experience, and apply various problem-solving techniques and strategies. Furthermore, the teacher must also provide tasks that are "challenging" and relevant to students so that students are encouraged to be actively involved in learning. In this way, the teacher indirectly facilitates students to achieve higher levels of thinking and increase their competence. In the end, through presentation activities or performance of what has been learned, teachers can find out to what extent the learning objectives that have been previously set can be achieved (Wicke, 2019).

Training on DACHL implementation for German language teachers in Malang has never been done before. In 2017, the authors conducted training on mapping the national exam questions for high school students based on the 2016/2017 national examination grid. Of course, this activity contains different subjects, even though the subject is the same, namely the German teacher in the Malang region. Meanwhile, another training that also discussed DACHL was

252 BRILIANT: Jurnal Riset dan Konseptual

Volume 6 Number 2, May 2021 
conducted by Risakota et al. in March 2020 with German teacher participants from Surabaya, Sidoarjo, and Tuban (Sumarno, 2020). Even though they both talk about DACHL, in training, the participants emphasize mastering digital learning media. In contrast to the author's training, where participants were trained to develop cross-cultural learning designs, mainly German and Indonesian cultures.

This learning design training provides many benefits for all parties involved. For target partners who are members of the IGBJI Malang branch, they can dig deep information about DACHL and its application in learning activities. For students, this activity can be used as a means of preparing themselves before they carry out practical teaching activities. For lecturers, this training is a forum for conveying thoughts and ideas to a wider audience.

\section{METHOD}

This training activity for the preparation of DACHL cross-cultural learning plans for German language teachers was designed by adopting an education and training system for State Civil Apparatus (Aparatur Sipil Negara/ASN), namely on campus and off-campus. When ON the participants came together to receive material about the DACHL concept, analysis of the DACHL concept in teaching materials, and the preparation of learning programs, and evaluation of the implementation of learning from the programs that had been compiled. Meanwhile, at the OFF time, participants were given the task to analyze the teaching materials used in daily German learning, make learning plans, and apply them independently in their respective assignments.

In order for the implementation of the training to run well and on target, cooperation was carried out with partners, namely the Malang branch of the Association of Indonesian German Language Teachers (IGBJI). The data that has been obtained from the implementation of the training are then analyzed in the 5 stages as follows: (1) collect the results of field notes and documentation, (2) collect the results of the activity evaluation from the participants through a questionnaire, (3) processing data from field notes, documentation, and evaluation, (4) describe the results of data processing, and (5) draw conclusions.

\section{RESULTS AND DISCUSSION}

The training for the preparation of the DACHL cross-cultural learning plan was not in accordance with the previously prepared plan due to the unfavorable field situation as a result of the development of cases of the spread of the COVID-19 virus from early March 2020. Originally planned there were five series of activity stages which included (1) delivery material on the DACHL Concept, (2) the delivery of material on the Integration of the DACHL Concept in Learning, (3) the development of a learning model, (4) the preparation of the DACHL learning plan and its implementation, and (5) the presentation of the results of the implementation of DACHL learning and evaluation of activities. was then shortened to three activities only because of the situation that did not allow. The implementation of the lesson plans and presentations on the implementation was not carried out considering that learning in schools also used online methods with very limited time. 


\section{Presentation of Material on the DACHL Concept Stage}

This first activity was held in the ON (face-to-face) mode in the SMA Negeri 8 Malang room on July 27, 2020. 23 German teachers from various senior high schools (SMA, MA, and SMK) in Malang followed suit. training from 09.00 to $12.30 \mathrm{WIB}$.

At the beginning of the activity, participants were invited to explore their knowledge again about DACHL by answering questions presented through the Quizizz application. Apart from questions about German, the quiz also includes questions about the natural and cultural conditions of the DACHL country. Based on the quiz score, it is known that the accuracy of the participants in answering only reached $40 \%$ as can be seen on the https:/quizizz.com/admin/quiz/5e562db9fc9489001bf663a5/dachl-quiz page. Of course, this value is low and represents that teachers' knowledge of the DACHL country is still minimal. After the quiz questions were discussed, the next step was the delivery of material about the concept of learning the DACHL culture.

Participants were divided into four groups, each of which was a group, namely Deutschland, Österreich, Schweiz, and Lichtenstein. Each group has the same task, namely seeking information about the country which is their group name from various sources, and then presenting it in the form of a placard (see Figure 1). The information that must be on the plaque includes the geographic conditions of the country, population, language, school system, political system, culture, and tourism. With the equipment provided, participants made placards and presented their work. From these presentations, participants can exchange information about DACHL countries so that they can gain better knowledge (see Figure 2).

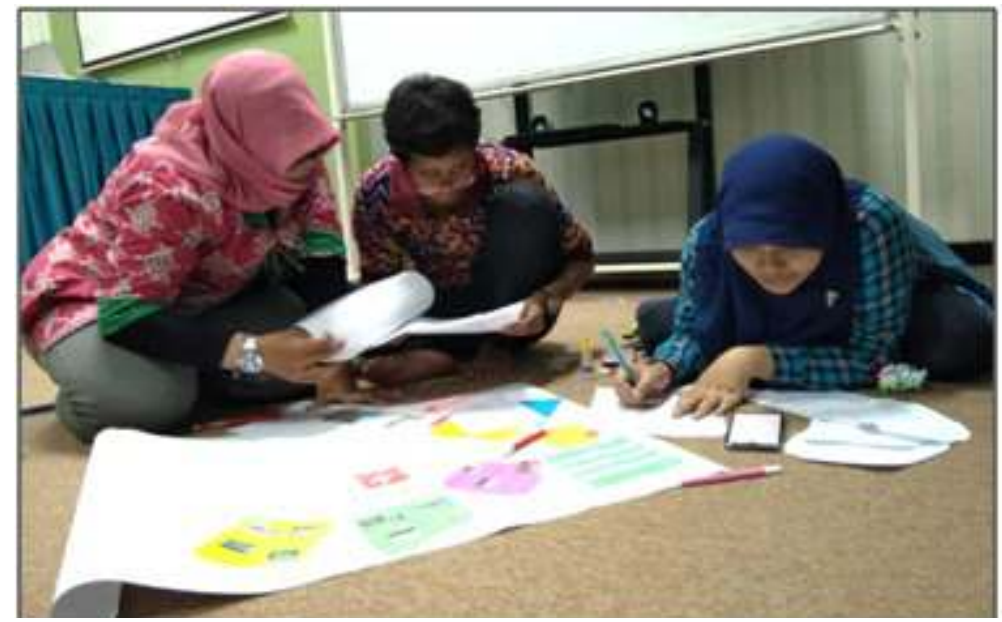

Figure 1. Development of a placard about the DACHL country 


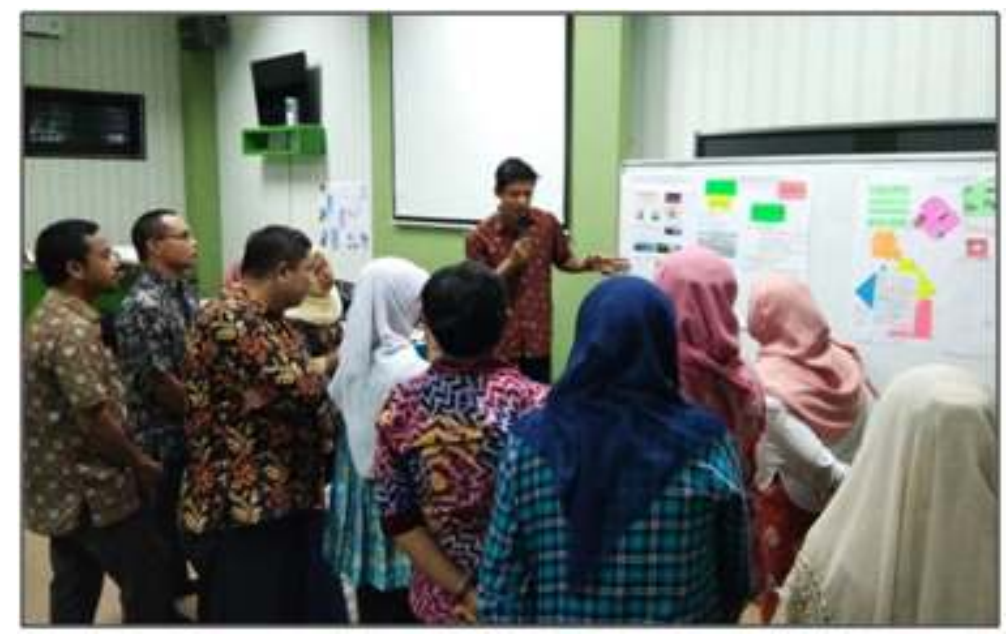

Figure 2. Placard presentation by each group

\section{Delivery stage of material on the integration of the DACHL concept in} learning and analysis of the DACHL concept in teaching materials

This second stage was held in the Mediothek room of the German Department, the State University of Malang on August 14, 2020. As was done in the previous stage, in this face-to-face $(\mathrm{ON})$ stage the participants were also divided into four groups. Each group gets one piece of text taken from the teaching material and they are asked to identify what information is contained in the text and present it in the form of a placard. The placard that has been made is then presented using the station learning method.

With this method, the plaque that has been made by the participants is affixed to the wall by providing a sufficient distance so that participants can move freely from one plaque to another (from one station to another). At each station, there must be one guard on duty to explain to station visitors about the material on the placard. Participants are free to choose which station to visit first according to their interests. After he got all the information and felt he had understood it, the participants moved to another station. Here the participants learn the material from each group according to their respective abilities (Binnendifferenzierung). As stated by (Klein, n.d.) this station learning method provides a very positive learning experience towards understanding material independently by learners and encourages flexibility in learning.

The next activity is still related to understanding the text about the origin of the term DACHL. Participants work in pairs (player A and player B), each of whom sits with his back to each other and gets the gaps text which must then be read in turn by dictating so that the missing information can be complemented by one another (see Figure 3). So, in the text for player A there is an answer from the gaps text that is owned by player B, and vice versa. Each pair receives a different text. To control the participants' answers, at the end of the section the full text is displayed through a PowerPoint display as well as a discussion of the content of the text being worked on. 


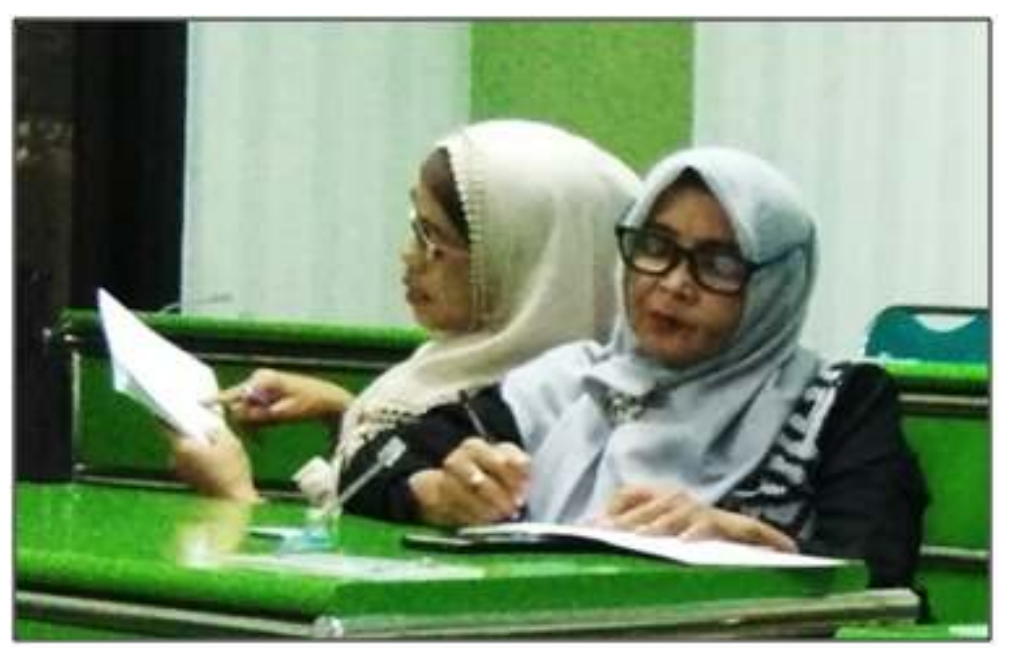

Figure 3. Participants doing the Rücken-an-Rücken-Diktat

This method is known in German as the Rücken-an-Rücken-Diktat. (Linowska, K., Weilandt, 2017) state that the Rücken-an-Rücken-Diktat method can increase student motivation. It is said so because this method presents a closed question form and the learner must be able to avoid mistakes when dictating his partner. As a follow-up to this stage, participants were asked to conduct an analysis of the DACHL material contained in the teaching materials that are used daily (OFF phase).

\section{Learning Model Development Phase, DACHL Lesson Plan Formulation, and Evaluation}

In line with the increasing trend of COVID-19 infection cases in the Malang area which does not allow face-to-face activities, the development stage of the learning model for DACHL material is carried out synchronously using the Zoom Meeting (ON) facility. This virtual activity was held on August 28, 2020, and was attended by German language teachers who had followed the previous stages.

At the beginning of the meeting, training participants were asked to present the results of the analysis of teaching materials which were carried out as an asynchronous task. Next is the delivery of material on the preparation of learning plans. Participants are presented with a learning material about DACHL and the steps to develop a lesson plan for this material. After that, participants were divided into five groups using the breakout room feature. In these groups, participants are free to choose which of the available materials they will develop a lesson plan for.

In addition to a description of the learning steps from start to finish, an important part that must also be defined by the group is the learning objectives and the method chosen. Well-formulated learning objectives not only help teachers in preparing material but are also very useful in establishing criteria for evaluating student learning progress (Döring, 2010).

After the groups finished compiling their lesson plans, they presented them. From this presentation, it can be seen that there are groups that have succeeded in compiling a lesson plan by integrating cross-cultural elements into it, 
but some have not. An example is group 4 discussing the theme Schultüte (school bags). In the lesson plans prepared, the group not only wrote steps about discussing Schultüte's text, but also included productive steps that students had to take, namely making their own Schultüte, making dialogues by mentioning the objects contained in Schultüte, and finally is making cultural comparisons about schools in Germany and in Indonesia. On the other hand, group 2 which discussed the theme Traditionelle Gerichte in Deutschland (German food), for example, in the lesson plans they compiled only steps for understanding text and vocabulary training through pantomime were formulated (see Figure 4). It does not include steps on how students understand the culture of the text presented, for example identifying which region the food comes from. The importance of emphasizing cultural understanding in foreign language learning and its integration in teaching materials has been conveyed by Bimmel et al. (Velica, 2010) and (Fräßdorf, 2013).

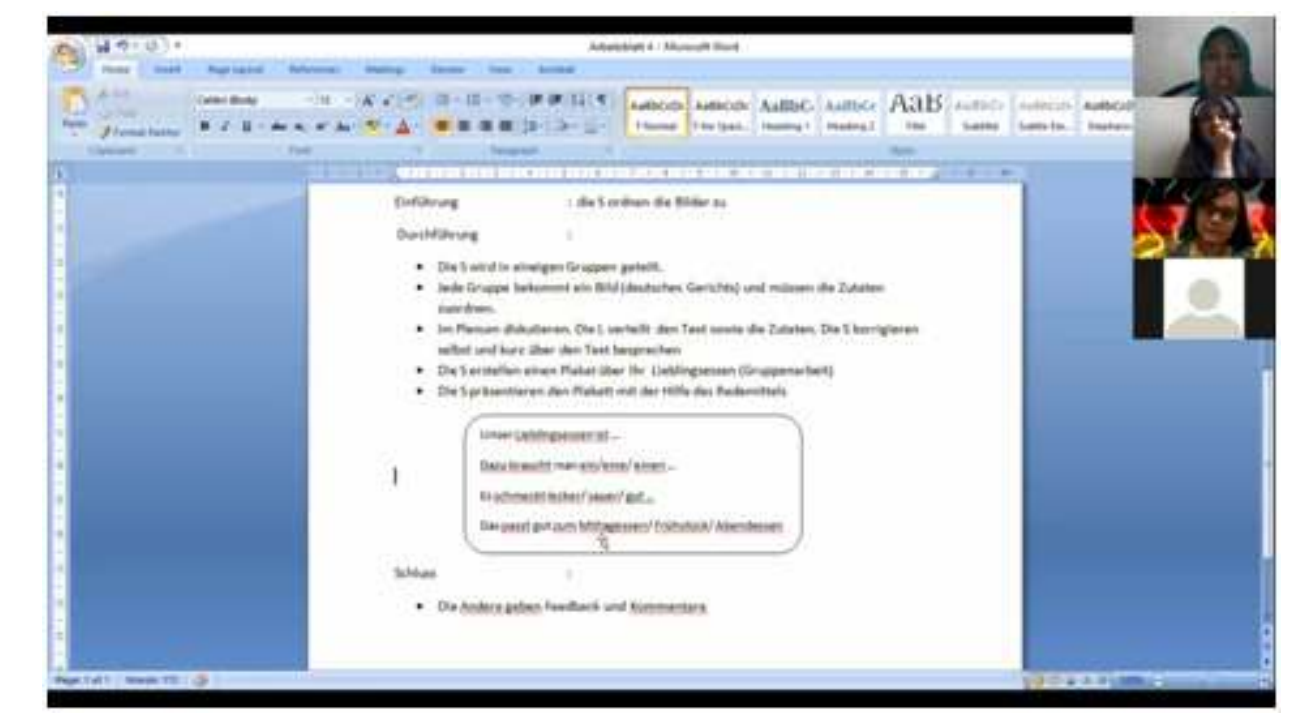

Figure 4. Presentation of the results of the preparation of learning plans using Zoom

At the end of the section, an evaluation of the implementation of training activities from the first to the last stage is carried out. Participants fill out a questionnaire that is presented in the form of a Google Form. The questionnaire asked participants 'opinions on matters such as training materials, the instructor's ability to deliver training materials, and participants' interests.

About half of the 23 participants (52\%) agreed that the material presented by the instructors in this training was new to them, $10 \%$ strongly agreed, and the rest disagreed. This finding is not surprising because some of the participants including teachers have attended a similar workshop organized by the Goethe Institut (GI) Jakarta when they accompanied their students in the Nationale Deutscholympiade (NDO) activities in January 2020. In addition, there are also teachers. from the Partnerschule school which specifically received assistance from GI Jakarta and was often sent to participate in similar activities.

As many as $74 \%$ of participants stated that the material obtained in this training is very suitable for their current profession and is very useful for their 
daily work. Before the material is delivered, the instructor tries to collect material according to the training target, namely teachers who teach German at SMA / MA / SMK with student levels A1 to A2. This is done to give the teacher a real picture of the DACHL material that can be presented in class according to the abilities of the students.

There were several questions that were asked related to the skills and abilities of the instructor in delivering training materials. These questions include (1) the ability of the instructor to convey material clearly and systematically, (2) the ability of the instructor to motivate participants to be actively involved in training activities, (3) the willingness of the instructor to help participants, (4) giving the opportunity to participants to ask the material which is not understood, and (5) the instructor's ability to answer questions from participants well. In general, the five points above received very positive responses from participants (Figure 5). In an open questionnaire, most participants expressed that group work was the most interesting thing they experienced during the training. As a form of cooperative learning, group work has many advantages.

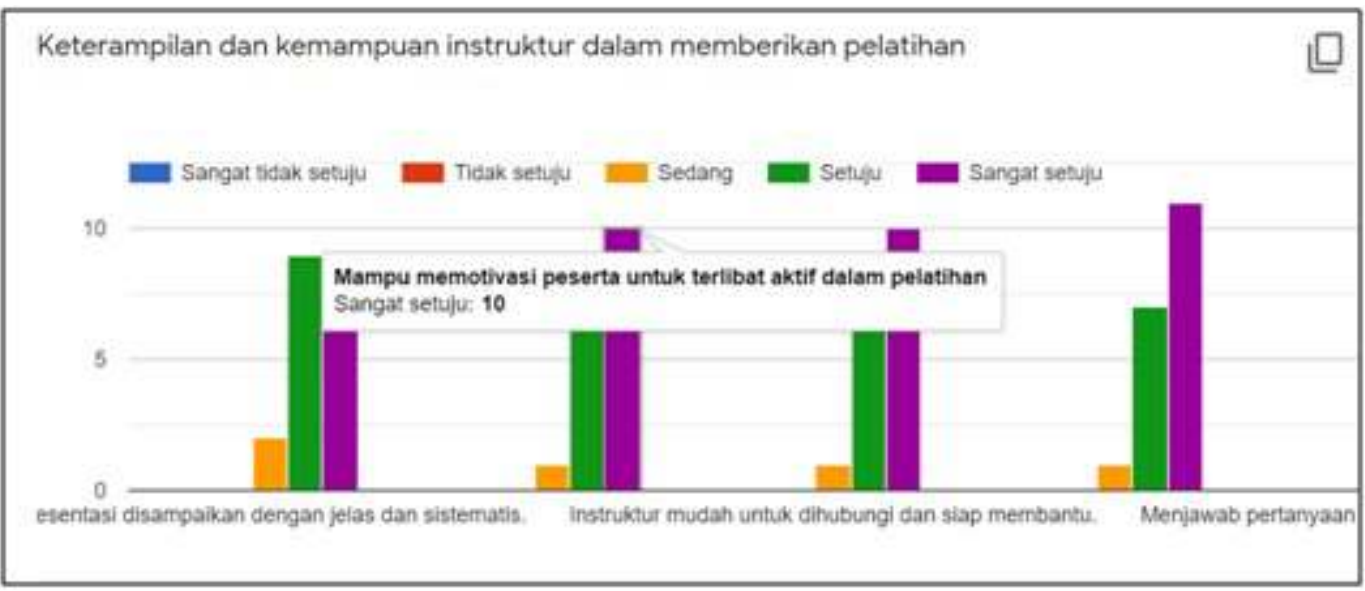

Figure 5. The results of the questionnaire on the skills and abilities of instructors in delivering training materials

(Lewis, 2019) stated that there are at least three advantages of cooperative learning, first changes in everything, second is life skills, and third is deeper learning. Cooperative learning enables teachers to handle a larger number of students. This learning model also changes the roles of students and teachers, where the teacher becomes a facilitator in learning and students become more responsible for themselves. Collaboration and cooperation are very important skills possessed by students and will continue to be used forever. Cooperative learning has also been shown to increase students' self-esteem, motivation, and empathy. In cooperative learning, students are often required to deepen their understanding of the assigned material. In addition, students are also involved in discussions about discourse with different perspectives. In connection with the role of instructors and participants in this training, it can be analogized that the instructor takes the role of the teacher and the participants act as students. 


\section{CONCLUSION}

The training for drafting a German language learning plan with the crosscultural theme of DACHL ran smoothly even though the method had to be adjusted as a result of the COVID-19 pandemic. Through simultaneous mentoring, training participants can receive this relatively new material well and simultaneously apply it in the form of a learning design. With collaboration and cooperation at every stage of the activity, training participants are not only encouraged to be able to work independently, but also be flexible in completing group assignments.

\section{SUGGESTION}

As previously mentioned, this training activity did not reach the implementation stage of the DACHL cross-cultural learning using a draft that had been prepared. Therefore, it is recommended that German language teachers who have attended this training can apply the knowledge they have acquired independently in the actual learning process. Collaboration between partners, in this case, German language teachers who are members of the IGBJI Malang Branch, with universities is a form of mutualism symbiosis that needs to be preserved. Apart from being a form of practicing the Tri Dharma of Higher Education, by being involved in community service activities, lecturers can find out about the latest developments in society and in the end also have an impact on the existence of the scientific field that is currently being worked on.

\section{REFERENCES}

Dengler, S., Rusch, P., Schmitz, H., et al. 2017. Netzwerk Deutsch als Fremdsprache A1 Kursbuch. Stuttgart: Ernst Klett Sprachen.

Der Internationale Deutschlehrerinnen- und Deutschlehrerverband e. V. (IDV). 2017. DACHL im Deutschunterricht. https://idvnetz.org/dachl-online/dachlim-deutschunterricht

Döring, S. 2010. Formulierung von Lernzielen - Didaktische Handreichung. https://tu-resden.de/mz/ressourcen/dateien/services/e_learning/didaktischehandreichung-formulierung-von-lernzielen-aus-dem-projekt-seco?lang=en,

Fräßdorf, D. 2013. Analyse des Deutsch-Lehrwerks "Schritte." GRIN Verlag.

Klein, R. n.d). Binnendifferenzierung durch Stationenlernen. Retrieved October 4, 2020, from https://www.wb-web.de/material/methoden/stationenlernen1.html,

Lewis, B. 2019. What Is Cooperative Learning? Teaching Students to Collaborate Effectively. https://www.thoughtco.com/what-is-cooperative-learning2081641

Linowska, K., Weilandt, J. 2017. Kannst $d u$ Deutsch sprechen? Kommunikationsorientierter DaF-Unterricht. http://forumdeutsch.ca/de/unterrichtsforum/kannst_du_deutsch_sprechen_k ommunikationsorientierter_daf_unterricht

Matthias Bischoff, et al. 2018. Fak̄ta Mengenai Jerman (L. Hermanto (Ed.)). Frankfurt am Main: FAZIT Communication GmbH.

Shutevski, D. 2016. Deutsch als Fremdsprache mit dem DACH(L)-Konzept. Einsatz im DaF-Unterricht und in Lehrwerken für Erwachsene. https://www.grin.com/document/335381 
Sumarno, J. T. 2020. Guru Bahasa Jerman di Jawa Timur Dorong Gunakan Media Digital.

Suarasurabaya.Net. https://www.suarasurabaya.net/kelanakota/2020/guru-bahasa-jerman-dijawa-timur-dorong-gunakan-media-digital/

Velica, I. 2010. Lernziele und deren Bedeutung im Unterricht. Neue Didaktik, 2.

Wicke, R. E. 2019. Taking Students Thinking to Higher Levels - Some remarks in favor of a creative and student-centered language teaching. Oral presentation on The Tenth Annual International Symposium of Foreign Language Learning (The 10th AISOFOLL). Bogor: Southeast Asian Ministers of Education Organization (SEAMEO) Regional Centre for QITEP in Language. 